\section{Questión}

Periodismo / Comunicación ISSN 1669-6581
- Av. $44 \mathrm{~N}^{\circ} 676,1^{\circ}$ piso

CP 1900 - La Plata - Argentina

(i) www.perio.unlp.edu.ar/question

\title{
LA VALENTÍA DEL SILENCIO, LA COBARDÍA DEL BULLICIO
}

\section{THE BRAVERY OF SILENCE, THE COWARDICE OF THE BUSTLE}

Omar Rincón / orincon@uniandes.edu.co Profesor Asociado de la Universidad de los Andes en Bogotá, Colombia, y director del Centro de Estudios en Periodismo y de la Maestría en Periodismo de la misma universidad. Investiga, ensaya y escribe sobre culturas mediáticas y estéticas del entretenimiento.

Ante esta COSA que nos pasó y se quedó a vivir con nosotros. Lo más bello, los más valiente, lo más sincero hubiese sido callarnos, habitar el silencio, encontrarnos en la escucha. Pero fuimos derrotados por el bullicio. $Y$ ese bullicio hizo que los progres nos sintamos payasos útiles del sistema, esa cobardía del decir nos llevó a decir lo obvio. Este es un testimonio de las obviedades, las mías, que son las únicas de las que puedo hacerme cargo.

Historieta 1 (27 de marzo)

\#Confluencers | Covid-19, los ganadores

Dije, como todos, lo obvio: que "los gobiernos podrán saltarse toda legislación de derechos humanos, toda legislación de respeto al ecosistema, porque ahora han decidido que seremos individuos controlados. Cero colectivo. Cero encuentro con el otro." $Y$ esto lo dije en un video https://www.youtube.com/watch? $v=3$ boD3YJapjw\&list=PLAHK5ntocYam4lumRaxhSMJNFV0m8lgS\&index=2 
Y dice así ESTE VIRUS... nos mandó a todos a casa y nos puso en modo HOME OFFICE... a vivir prisioneros de nosotros mismos... la prisión perfecta... pero con la felicidad de tener tecnologías digitales para estar en el mundo...y los ganadores son...

1. Las empresas tecnológicas que podrán ejecutar su fracasado plan $5.0 \ldots$ que consiste e irradiar el mundo de energías electromagnéticas... afectando todito el ecosistema... produciendo nuevos virus... con la promesa de todos vamos a estar conectados...

2. $Y$ ganadores son las empresas que gestionan datos... porque para estar conectados desde casa regalamos nuestros datos... y las empresas y universidades les compran programas y les pagan y les regalan los datos más cualificados...

3. Y ganadores son Google, Facebook, Netflix... porque todo nuestra comunicación y estilo de vida dependerá de ellos...

4. Y ganadores serán los gobiernos... que controlarán ciudadanos en su anomia social: individuos... cero colectivo

5. Habrá contaminación del dato, ya que subimos millones de basura y saturamos el ecosistema digital... y pagamos por guardar basura digital... y habitaremos la no sostenibilidad digital del planeta

En conclusión: estamos envenenando el ecosistema con energías electromagnéticas que conllevan mas devastación natural y simbólica... estamos haciendo más ricos a las empresas tecnológicas... estamos celebrando la prisión del individualismo

Pero... para no ser aguafiesta...

1. Demuestra donde hay líderes que guíen nuestro mundo: Brasil, Colombia y USA no son ejemplos

2. El capitalismo se tiene que repensar en su lógica financiera y de consumo... la mayoría está quedando por fuera del sistema

3. Luchar contra el calentamiento global es la única solución y se puso de moda

4. El feminismo y su filosofía del cuidado, el vínculo es la solución.

Historieta 2: (25 de marzo)

El crónica virus: El nuevo periodismo deportivo 
Y escribí en 070. https://cerosetenta.uniandes.edu.co/el-cronica-virus-el-nuevo-periodismodeportivol

El corona virus expulsó el futbol de los medios y redes, pero tranquilos, los medios y periodistas narran al Covid 19 como si fuera un partido de fútbol: el espectáculo y la emoción en directo narrado desde hinchas más que desde periodistas y ciudadanos.

El virus coronó. El virus se volvió crónica, pero no periodística. El virus devino Covid 19 (nombre técnico).

El virus vive feliz en los medios. Caracol Televisión compungido comunica: "En Caracol Televisión nos sumamos a los esfuerzos del Estado Colombiano, en búsqueda de prevenir y dar a conocer los controles de salud frente al Covid-19 (más conocido como Coronavirus). Teniendo en cuenta lo anterior hemos tomado la decisión de ampliar el horario de algunos espacios informativos con el objetivo de mantener al país oportunamente enterado de la evolución de esta situación, por lo que se podrán dar cambios en nuestra programación habitual. En Caracol Televisión lo más importante es la gente y su salud; por lo que nos sumamos como compañía en establecer medidas de prevención oportunas con el fin de cuidar la propagación del virus en nuestra comunidad. Así mismo, garantizaremos la mejor y más responsable información en tiempo real, y nuestras audiencias podrán continuar disfrutando de la mejor programación familiar con la que siempre los hemos acompañado".

Dos perlas: "En Caracol Televisión lo más importante es la gente y su salud" y "garantizamos la mejor y mas responsable información en tiempo real". Y para hacerlo nos cuentan esas noticias terroríficas del coronavirus con un dejo de emoción futbolera: cada contagiado es un gol que se narra, cada comentarista es un fanático que inventa análisis, el árbitro un gobierno mete más miedo y todos somos barras bravas dispuestas a linchar o reír. $Y$ todo en directo y en vivo: no hay pausa, ni reflexión, ni esperanza, ni humor, ni ambigüedad: y otro virusiado, gol y goool y gooolll.

Así el coronavirus se convierte en miedo mediático ya que nos dice que el mundo real-real es una amenaza, luego mejor quedarnos en casa y ver fútbol, deportes, telenovelas, realities para ser espectadores de las miserias humanas y políticas. Así creamos el comportamiento perfecto: estamos en casa viendo la tele porque el afuera real es amenazante, sobre todo porque los humanoides son poco confiables en sus cuerpos. 
Menos mal que este virus es "viral" digital ya que allí al lado de los miedos y el terror, aparecen los chistes, las parodias, los tutoriales y las dudas.

En todo caso, tranquilos, los medios y las redes son el lugar seguro de contagios corporales, aunque propaguen los miedos públicos. La propuesta de los medios, las redes y Duque es la misma que para solucionar el virus: lavarse las manos de su responsabilidad.

En este contexto, ¿qué deberían hacer los medios y el periodismo para informar sobre este virus?

REPORTEAR, NO ANALIZAR. Taylor Mulcahey de la Red Internacional de Periodistas recomienda que como es poco lo que se entiende, lo único que queda de real-real es hacer reportería. Y cuando se hace hay mucho que conversar pero poco que mostrar: mucho tilín tilín de gobiernos y analistas y pocos hechos.

OJO CON LOS TÍTULOS. No se trata de un gol, no se cuenta cada viruseado como un gol patrio, no se comunica cada miedo con la emoción del hincha. Más que nunca se necesita y exige contexto.

CONTEXTO. Martín Caparrós en el New York Times nos cuenta que en el invierno 2018-2019 en España fallecieron 6300 personas por gripe. "Un montón de muertos", y que "quizá los grandes medios, siempre quejosos, siempre atentos a estas cosas, descubran por fin su panacea: si empiezan a transmitir en directo cada nueva víctima de la gripe podrán considerando que la temporada griposa dura menos de medio año- ofrecer unos 35 óbitos al día, un par por hora en las horas despiertas, un espectáculo incesante, un terror sin medida. Por ahora no lo entendieron y se limitan al coronavirus: treinta y tantos muertos en España, todos muy mayores". Antes que el directo, el en envío primero es el contexto, sin contexto no hay sentido.

TUTORIAL. Mas que informar primero, se debe hacer periodismo lento, comprensible y explicativo. Un tutorial que desactive los miedos y active al ciudadano. No se trata de producir terror, sino de colaborar en la generación de confianza. 
PERIODISMO LENTO. No al directo, al en vivo, a la alarma. Sí al pausar, tener datos, verificar los datos, evitar a los expertos opinólogos, ganar el criterio. Esto significa a renuncia al periodismo de "todo por un clic" para hacer el periodismo que provee criterio.

MENOS ES MÁS. Recordar que este virus no es un partido de fútbol, que cada enfermo no es un gol, que cada decisión de los gobiernos no es un cántico de barra brava. Menos es más, pero un menos con conciencia social y responsabilidad democrática.

Historieta 3 (31 de marzo)

Acerca de los bienpensantes de este mundo...

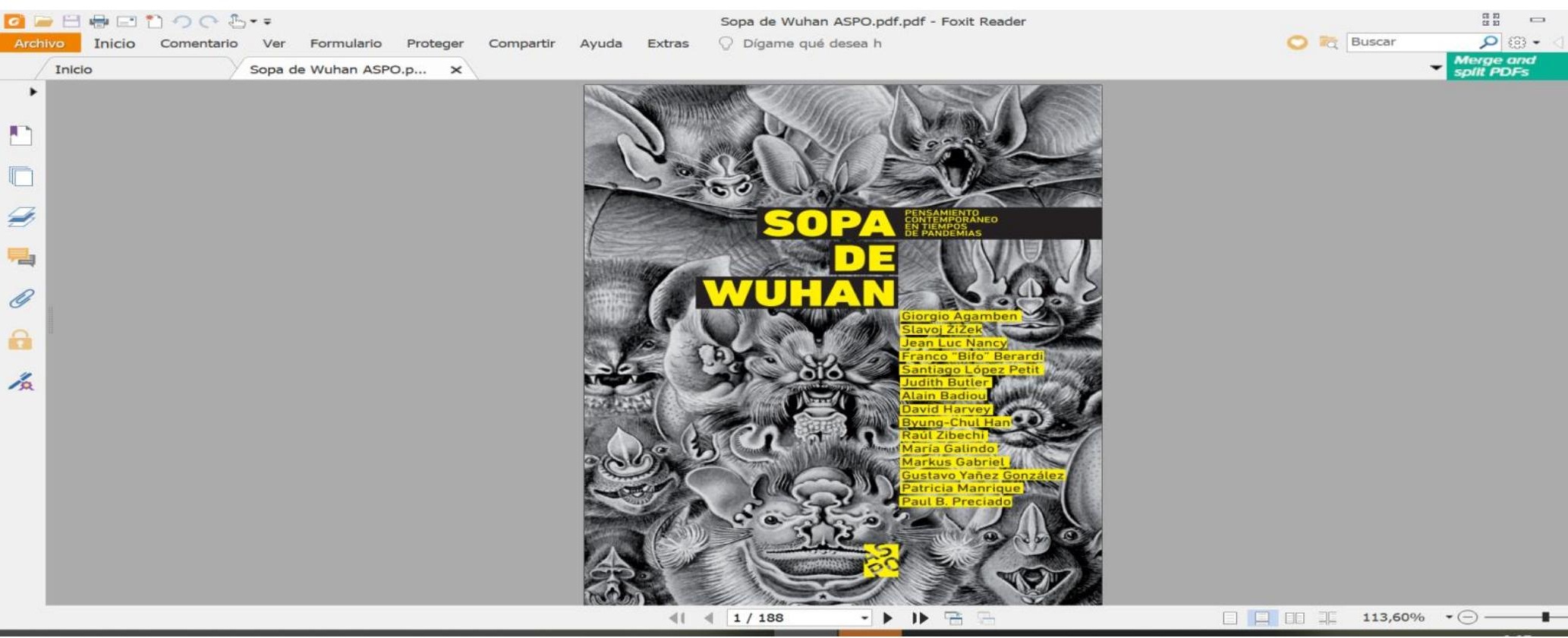

J. j!!Tremenda compilación!!!

0 . Aunque aburre tanto sabio junto.

J. Es raro que analicen algo tan pronto... Pero bueno, digamos, que hay tiempo para leerlos. 188 páginas! 
O. Hay apuntes... Lo raro es como se toman tan en serio. Se sienten iluminados, y nos están iluminando. $Y$ mientras tanto Trump Bolsonaro Duque y el capitalismo ni se entera. Es raro. Para los que decide (payasos políticos, empresarios, fondos de inversión (especuladores de bolsa), los dueños de la verdad dios (iglesias) y de la verdad de sus amos (los medios): ellos y ellas y esos pensamietos no existen.

Parece que

Giorgio Agamben

Slavoj Zizek

Jean Luc Nancy

Franco "Bifo" Berardi

Santiago López Petit

Judith Butler

Alain Badiou

David Harvey

Byung-Chul Han

Raúl Zibechi

María Galindo

Markus Gabriel

Gustavo Yáñez González

Patricia Manrique

Paul B. Preciado

son útiles al sistema... su asunto es parte del mantener ocupadas a las mentes que problematizan. Hacer sentir felices, sabios y profetas a sus iglesias. Parecer todos progres y contraculturales.

J. Esto es muy frustrante. No se enteran

O. Creo que la academia y más la que se cree progre, son los bufones útiles para que estos troglos dominen. No le hablan sino a evangelizados, yo uno de ellos.

$* * * * *$

Y Pere Ortín, el amigo dada contra el periodismo gagá, el amigo collage de Altair ...esto me contó por guasá... 
Sobre estas opiniones...El otro día me preguntaba ¿porque hay que opinar y decir todo el día todo el rato de todo y todo el tiempo?

Ellxs, filósfxs pros, ¿no tienen (también) una responsabilidad social añadida con nosotros en sus ignorancias? ¿Por qué nos cuesta tanto decir "no sé"? ¿Por qué se ha hecho tan difícil la perplejidad el silencio?

Recuperar el rigor paciente del silencio me parecería un ejercicio de honestidad muy necesario y saludable en estos tiempos convulsos en los que la biología evolutiva (a través de un virus y una vez más) nos deja sin palabras a los superinteligentes humanos que seguimos pensamos que desde un vacuo culturalismo humanístico se puede explicar el mundo y la vida cuando es muy evidente (siempre lo ha sido) que no es así...

Leía y pensaba en el tiempo y la velocidad: ¿por qué tienen que 'decir'? ¿Por qué no escuchan cómo cambia el mundo antes de describir esos cambios? ¿Son 'griots' o creadores de crucigramas en un mundo (ellxs incluídos) sin palabras?

No es ninguna crítica, es reflexión con preguntas y deseo de autoexigencia: que alguien te pida opinión no te obliga a darla si no sabes o no entiendes, o no eres capaz (aún) de aportar algo relevante, distinto, sobre lo que nos sucede.

Estoy $100 \%$ de acuerdo en q cada cual escribia y diga lo que desee y o le de la gana, y por eso creo también que, tras tantos y tantos errores de apreciación filosófica e ideas-predicciones de Nostradamus, yo solo les agradecería un poco + de Ludwig, ¿no te parece?

Hay que reflexionar frente a estos pensamientos filosóficos de urgencia, sin filtro, atropellados: su problema es que está hecho sin método y sin rigor racional porque no tiene tiempo suficiente para pensarse contra sí mismo y, por tanto, corre el peligro de convertirse en aliado del delirio

En estos tiempos convulsos, creo q esa "exigencia" específica aplica (no solo a las estupideces de nuestros políticos Bolsonaros, Trumps, Amlos y Duques o a intelectuales y periodistas) sino más aún si cabe a estos filósofos relevantes y a sus productos culturales urgentes de hechos sin un mínimo rigor, tiempo y seriedad.

Y luego esta el supremacismo cultural de lo que llamo los nuevos racismos cosmopolitas: ¿Por qué nunca sacamos filósofos africanos negros? O ¿latinos? Es, sencillamente, porque no los conocemos; o porque directamente pensamos en Occidente que no piensan y no tienen nada 
que aportar(nos) en el debate global sobre lo que nos sucede? Siempre me aturde esa cuestión de la "cultura-culture-coolture" occidental global

Hay que colaborar a situarnos de forma rápida y en chispazos, a leer el mundo como una especie de necesarios historiadores urgentes del presente (y eso tiene mucho valor), pero Butler, Zizek, Preciado etc etc deberían hacer otra cosa más seria, relevante y valiosa, porque tienen otras "responsabilidades" significativamente diferentes (tanto en magnitud como en ambición intelectual de permanencia) a las opiniones en prensa sujetas a las normales esclavitudes de toda opinión en un medio de comunicación (formato, extensión limitada, presentismo, medio y criterio del editor, urgencia, etc)...

En fin...son solo unas notas para apuntalar mi análisis crítico "de urgencia" de esto que nos pasa y que, también, nos hace pensar sin rigor, sin método...jajaja (:) 숭

Y no pude callarme. Y dije en otro video: \#Confluencers I Callar y escuchar (abril 15)

\section{: https://www.youtube.com/watch? $v=v W--4 X 4 j s p w$}

Acerca de los bienpensantes de este mundo...

Ante la COSA... deberíamos tener la valentía de callarnos, el silencio, la escucha...

Pero... tengo que hacer este video, entonces, hablaré de los que hablan

1] En Política... Trump, Bolsonaro, Amlo, Piñera, Lenin, Bukele, Johnson, Duque... líderes que no guía a nadie y no saben pero se la creen... pero es bueno que estén, están matando al capitalismo

2] En el pensar... la Sopa de Wuhan

12 manes Agamben, Zizek, Nancy, Berardi, López Petit, Badiou, Harvey, Byung-Chul Han, Zibechi, Gabriel, Yáñez González, Preciado

3 mujeres: Judith Butler, María Galindo (boliviana), Patricia Manrique

* Se toman tan en serio, nos están iluminando. Los hace sentir felices, sabios y profetas a sus iglesias. No le hablan sino a evangelizados, yo uno de ellos.

* Trump bolsonaro duque y el capitalismo ni se entera. Es raro para los que deciden: ellos y ellas y esos pensamientos no existen.

* Somos los bufones útiles para que estos troglos dominen. 


\section{ENTONCES,}

* Acudir a la interculturalidad

* Escuchar a los que tienen algo que decir: Las mujeres en territorio y los sabedores ancestrales y afros ... al sur, a los otros, menos blanco, occidental y machos...

* Recuperar el rigor paciente del silencio

Estoy $100 \%$ de acuerdo en q cada cual escribia y diga lo que desee y o le de la gana mínimo rigor, tiempo y seriedad.

Historieta 4 (4 de abril)

En modo cuadritos

Publicado en El diario del año del virus https://cerosetenta.uniandes.edu.co/tema/blog/diariodel-ano-del-virus/

Esta COSA que estamos viviendo me recordó una película y una canción.

La película ¿Y su mamá qué hace? (1981) dirigida por Eulalia Carrizosa y producida por Cine Mujer. Y la recordé por el final... que no les voy a contar para que la vean y cuya sinopsis podría ser una mamá en cuarentena. Y si es por echar cuento pues habla de las mamás a quienes en esta COSA estamos amando como nunca porque nos damos cuenta que son las que mantienen este mundo en modo activo.

Y la canción es del Gran Combo de Puerto Rico y se llama $Y$ no hago mas naa (1991). Y la recordé porque expresa lo que muchos, sobre todo los jefes y dueños de los destinos, creen que nos está pasando a profes, estudiantes, desempleados y demases. $Y$ dice así:

"Yo me levanto por la mañana

me doy un baño y me perfumo

me como un buen desayuno

y no hago mas na'... mas na"'

$Y$ termina así:

"que bueno es vivir así comiendo y sin trabajar

que bueno es vivir la vida 
comiendo durmiendo y no haciendo na

que bueno es vivir así comiendo y sin trabajar"

Pero el "mas naaa" es vivir la vida en cuadritos y sin comentarios.

Mas naa 1.

Sicua plus expandido en modo colaborativo donde uno no ve a nadie ni oye a nadie, bueno tampoco se ve a uno mismo.

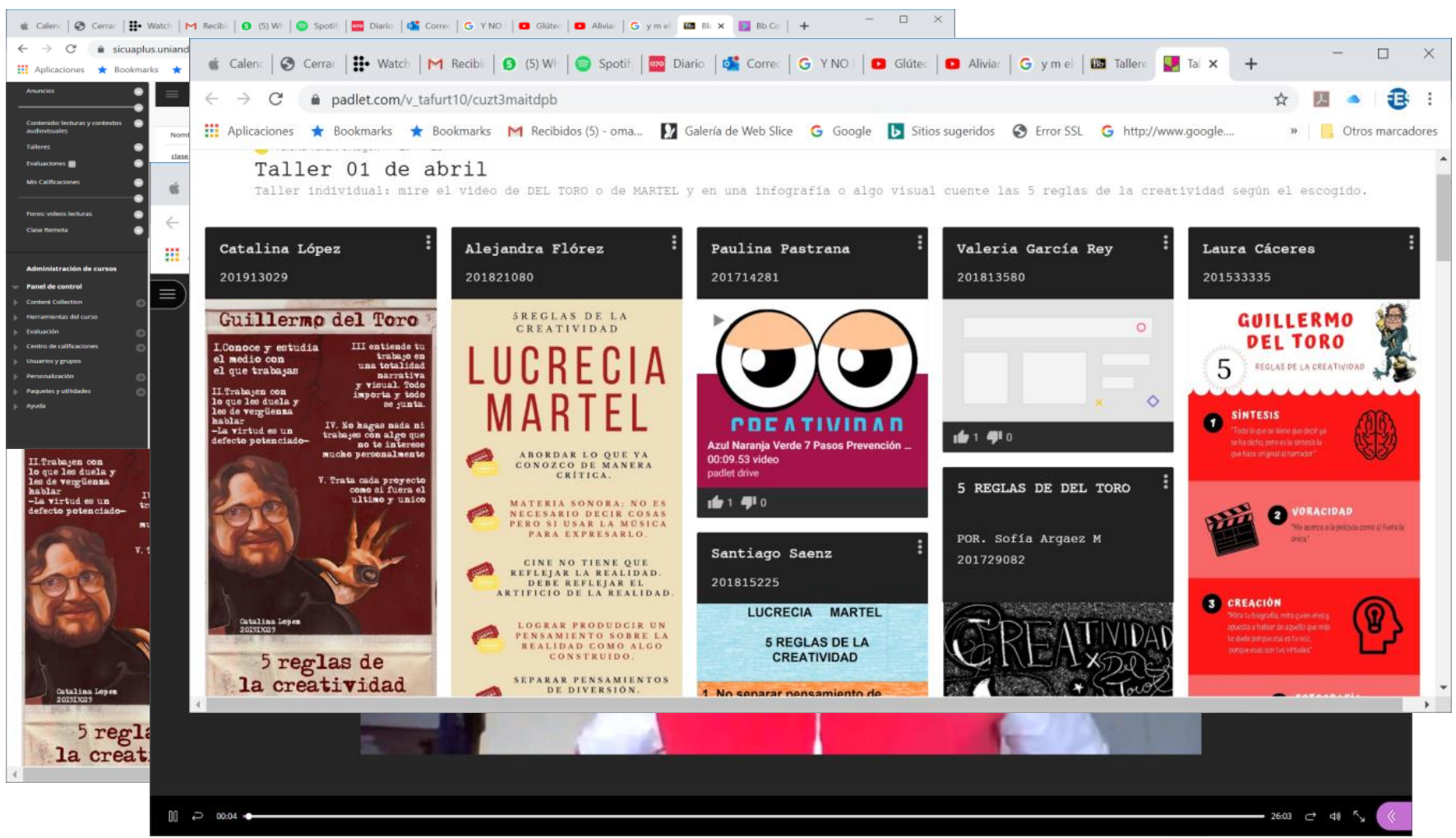

Mas naa 2.

Seminario Internacional con colegas del mundo para desaburrir a la COSA e intentar teorías desde el sur para construir una comunicación mas desde el territorio y en coherencia con el medio ambiente y los saberes ancestrales 


\section{(C) $(1)(9)$}

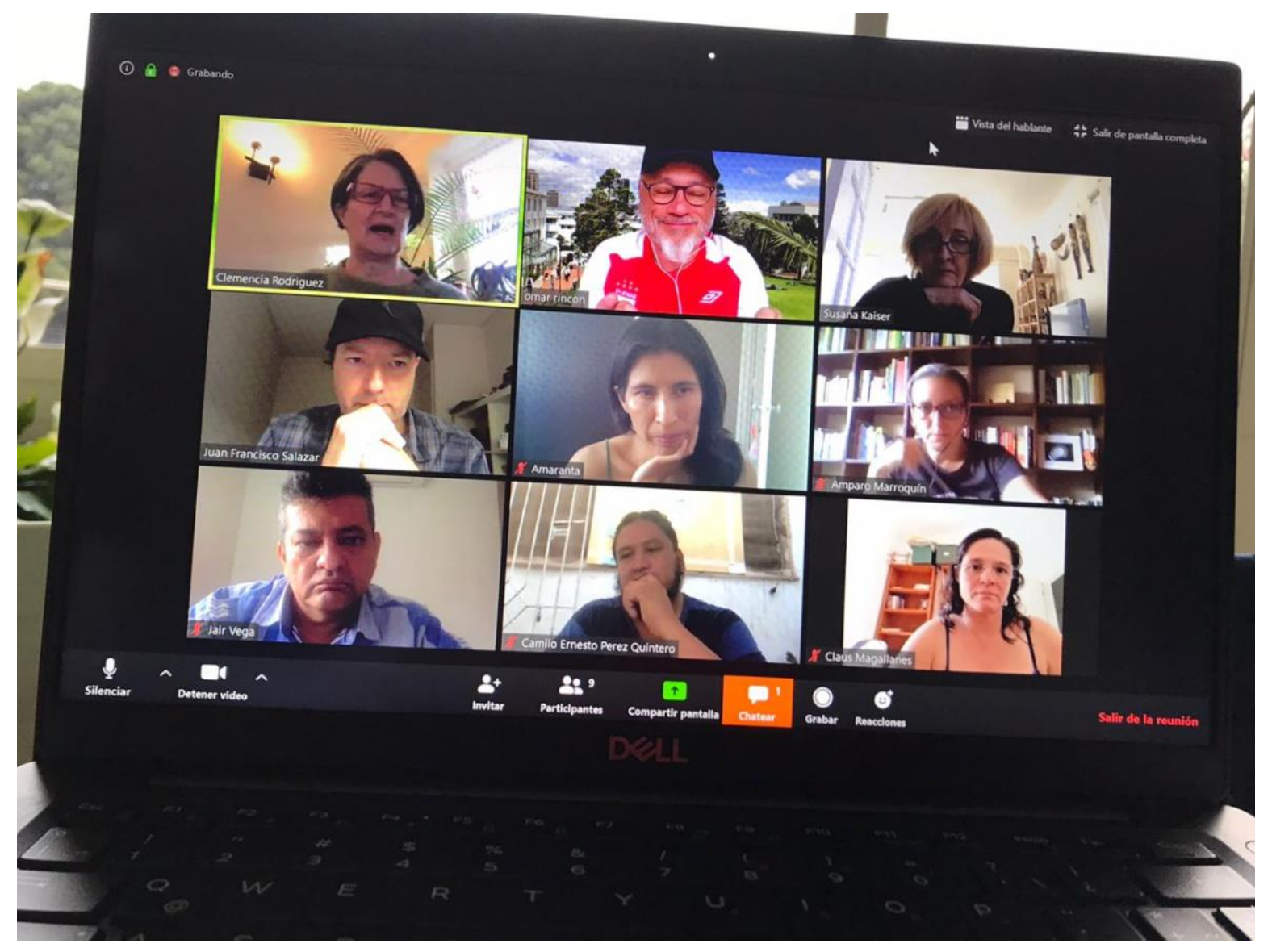

Mas naa 3.

Almuerzo con amigues de Barcelona, México y el parque El virrey. La idea es querernos y, además, intentar imaginar otro periodismo. 


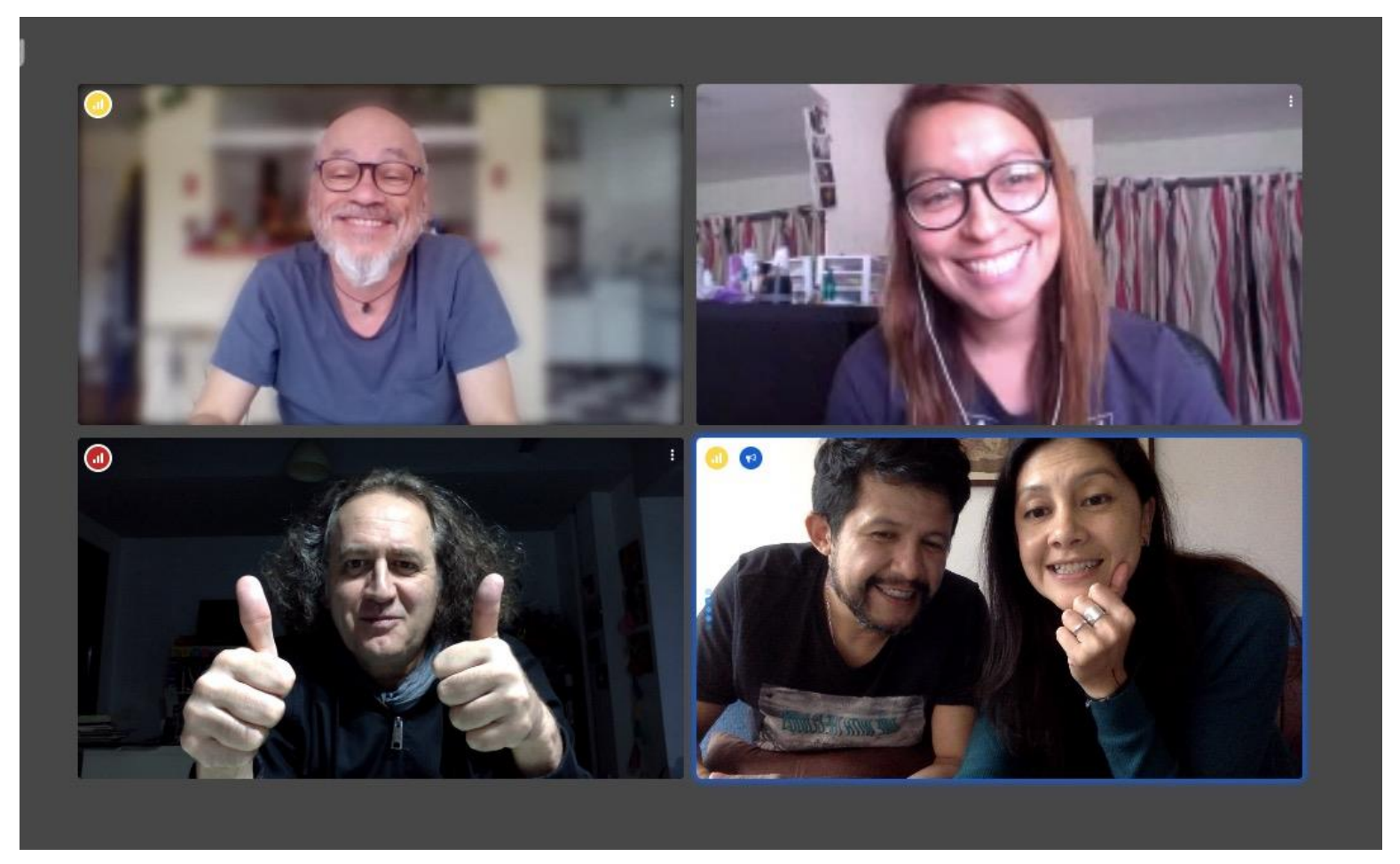

Mas naa 4.

Vino de tarde con España y El Salvador para ir intentando salirnos de LA COSA con un poco de sentido si es que los políticos nos dejan opinar y disentir. 


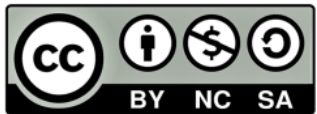

Esta obra está bajo una Licencia Creative Commons

Atribución-NoComercial-Compartir Igual 4.0 Internacional

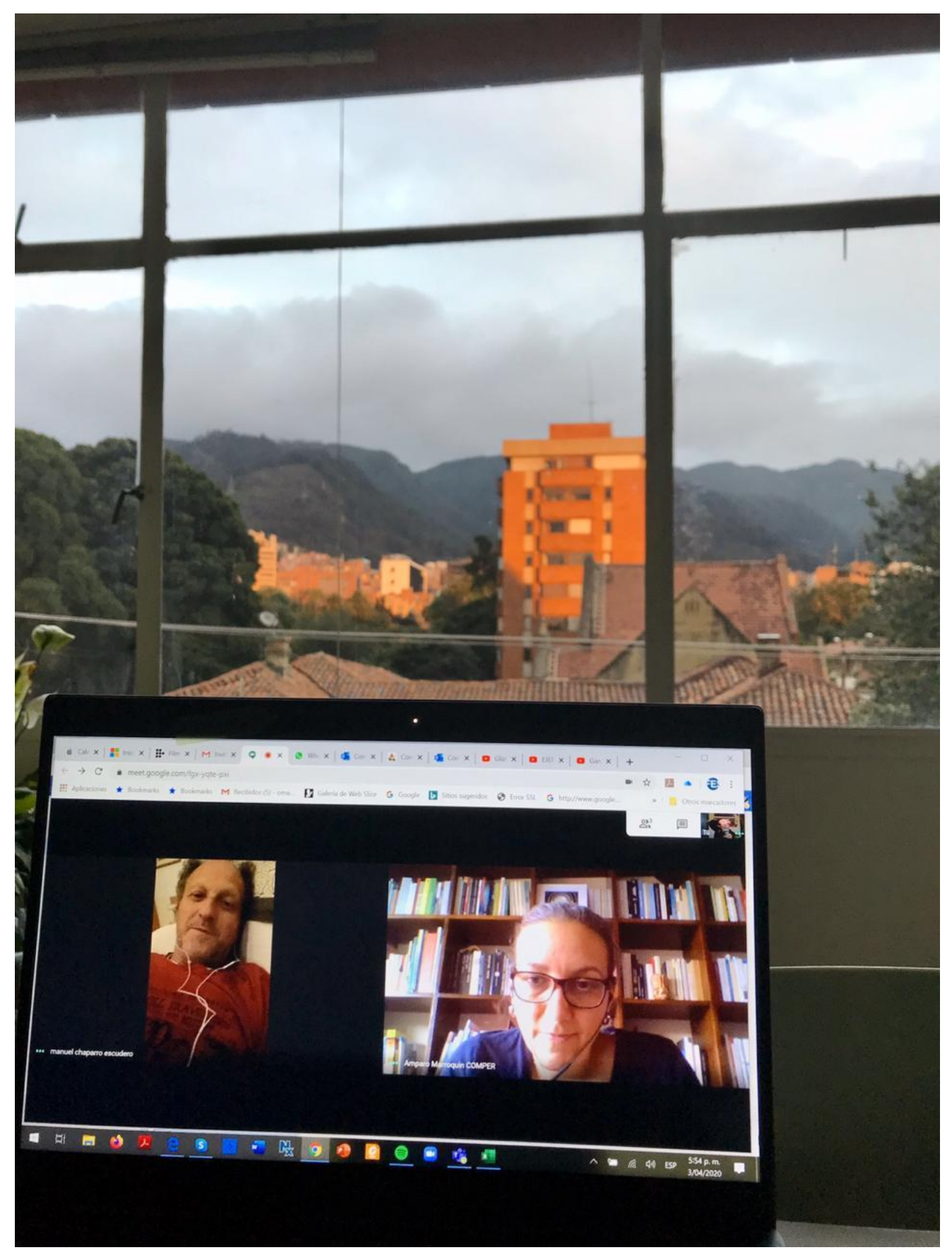

Mas naa 5. 
Rumba viernes 11 de la noche. 60 amigues. Cada uno en su modo. Aburrido el modo en uno.

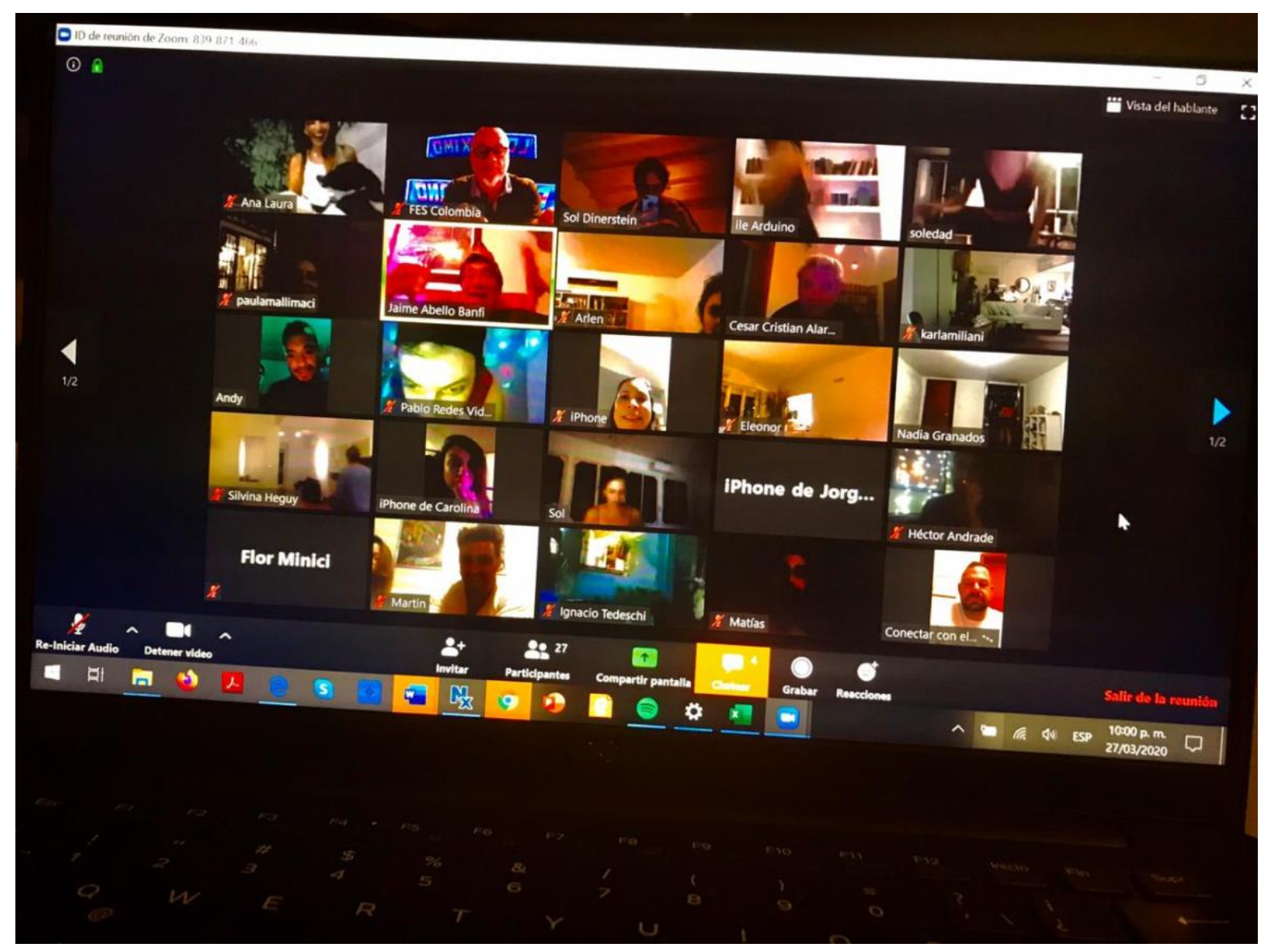

Mas naa 6.

Preparar

clase.

Revisar asignaciones.

Lavar platos, lavar platos, lavar platos. Barrer, trapear, limpiar. Lavar la ropa.

Asistir a comité remoto $1 \ldots$ a comité remoto $2 \ldots$ a reunión remota $3 \ldots$ a entrevista remota $4 \ldots$

Y leer literatura, y ver series, y ver películas, y ver lo que hacen los amigues. Y de ahí mis recomendaciones:

1. Historias breves desde la gente. Vokaribe Radio.

https://soundcloud.com/vokaribe/sets/te-escuchamos-relatos-de 


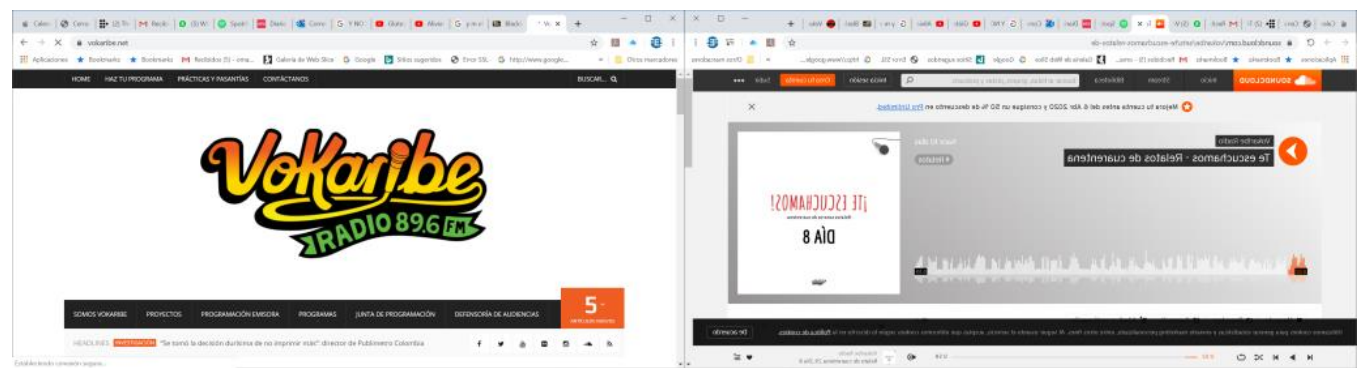

2. Modo viaje, ya que no se puede, viaje collage. Altair Magazine. Pere Ortín. https://www.altairmagazine.com/voces/kagura/

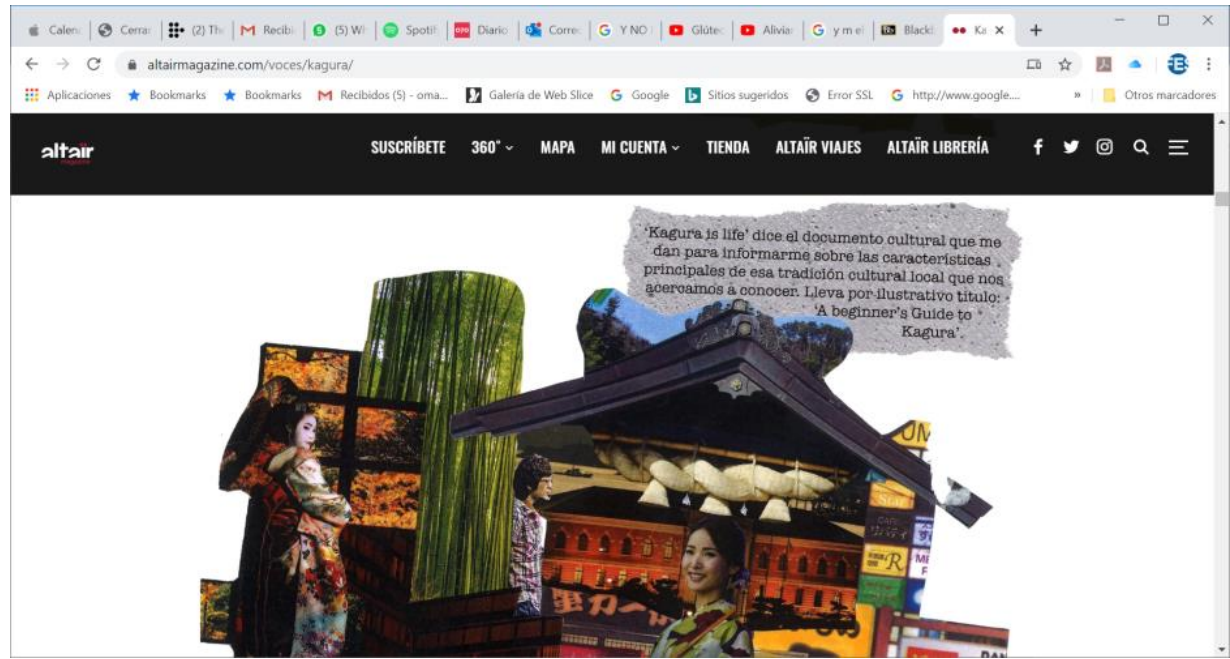


3. Ver en Mubi: LAS HIJAS DEL FUEGO de la argentina ALBERTINA CARRI... no tiene pierde. Bella, provocadora, contundente. Como dice el maestro Jesús: “Tomeeee!".

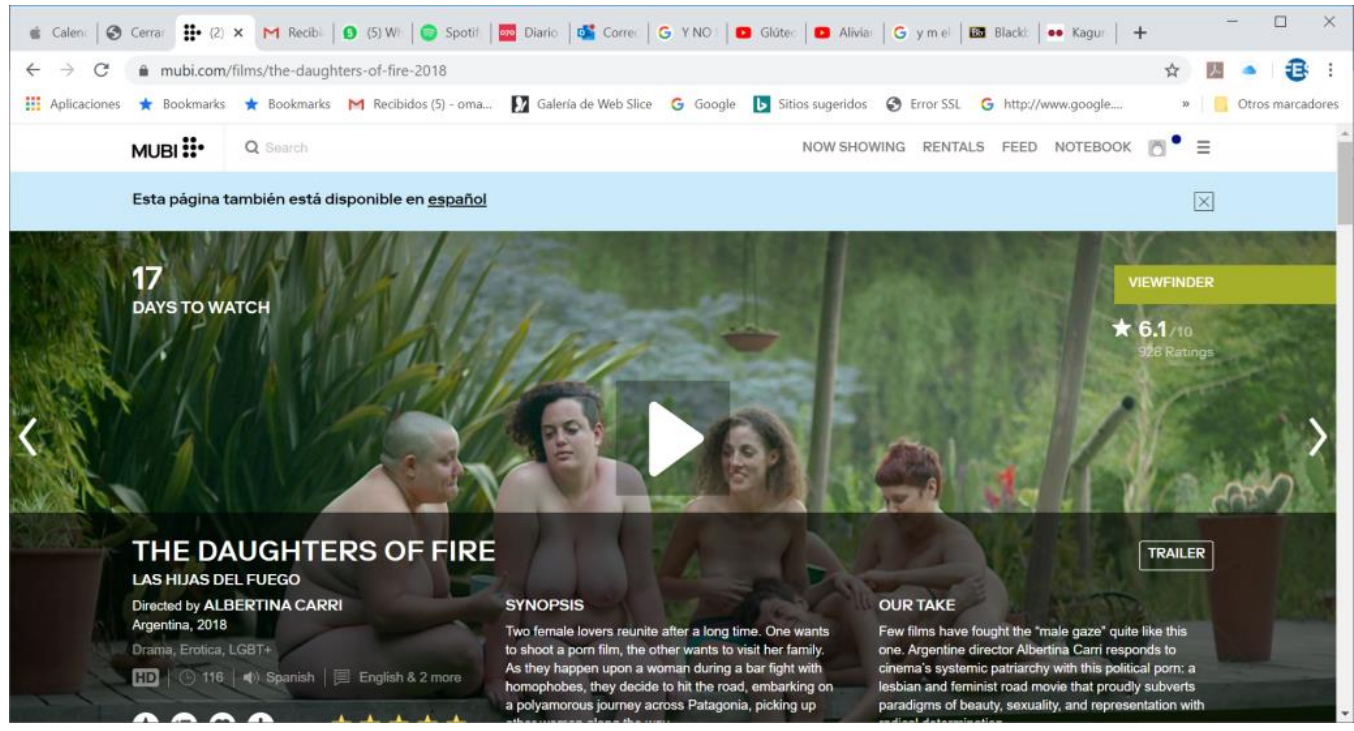

